\title{
Editorial
}

\section{Theoretical Investigation on Non-Covalent Interactions}

\author{
Alexander S. Novikov ${ }^{1,2}$ (D) \\ 1 Institute of Chemistry, Saint Petersburg State University, Universitetskaya Nab., 7/9, \\ 199034 Saint Petersburg, Russia; a.s.novikov@spbu.ru \\ 2 Infochemistry Scientific Center, ITMO University, Kronverksky Pr., 49, Bldg. A, \\ 197101 Saint Petersburg, Russia
}

\begin{abstract}
This editorial is dedicated to announcing the Special Issue "Theoretical investigation on non-covalent interactions" of Crystals. The Special Issue covers the most recent progress in the rapidly growing fields of data science, artificial intelligence, and quantum and computational chemistry in topics relevant to the problem of theoretical investigation on non-covalent interactions (including, but not limited to, hydrogen, halogen, chalcogen, pnictogen, tetrel, and semi-coordination bonds; agosic and anagosic interactions; stacking, anion-/cation- $\pi$ interactions; metallophilic interactions, etc.). The main successes of my colleagues and I in the field of fundamental theoretical studies of non-covalent interactions in various chemical compounds over the past year are briefly highlighted.
\end{abstract}

Keywords: non-covalent interactions; computer modelling; computational chemistry; data science; crystal engineering

check for updates

Citation: Novikov, A.S. Theoretical Investigation on Non-Covalent Interactions. Crystals 2022, 12, 167. https://doi.org/10.3390/ cryst 12020167

Received: 4 January 2022 Accepted: 8 January 2022 Published: 24 January 2022

Publisher's Note: MDPI stays neutral with regard to jurisdictional claims in published maps and institutional affiliations.

Copyright: (c) 2022 by the author Licensee MDPI, Basel, Switzerland. This article is an open access article distributed under the terms and conditions of the Creative Commons Attribution (CC BY) license (https:// creativecommons.org/licenses/by/ $4.0 /)$.
Non-covalent interactions are a hot topic in modern crystal engineering and related fields of material science. Non-covalent interactions are the driving force in the creation of innovative compounds with valuable optical, mechanical, magnetic, and redox properties, and they are promising for the manufacture of liquid crystals, porous structures, battery cells, LEDs, sensors, and many other smart materials.

Modern methods of data science, artificial intelligence, and quantum and computational chemistry are widely used for the investigation of nature and various properties of different non-covalent interactions (hydrogen, halogen, chalcogen, pnictogen, tetrel, and semi-coordination bonds; agosic and anagosic interactions; stacking, anion-/cation- $\pi$ interactions; metallophilic interactions, etc.). Computer modeling could provide a solid theoretical background for understanding the matter on a molecular and supramolecular levels.

Thus, the theoretical investigation of non-covalent interactions is a cutting-edge direction for research in chemistry and related fields of knowledge (crystallography, biology, physics, mathematics, computer science), and this Special Issue of Crystals "Theoretical investigation on non-covalent interactions" is open for contributions from both junior and senior researchers. All types of papers (reviews, full papers, communications, technical notes, highlights, etc.) are welcome for consideration.

In this editorial, I would like to briefly highlight the main successes of our research group in the field of fundamental theoretical studies of non-covalent interactions in various chemical compounds over the past year.

The IsoStar program suite for studies of non-covalent interactions in crystals of chemical compounds was discussed in [1]. Our group reported the combined experimental and theoretical study of bifurcated halogen bonding involving diaryliodonium cations as iodine(III)-based double- $\sigma$-hole donors-all recognized bifurcated halogen bonds with diaryliodonium cations were classified and divided into two categories: "bifurcated plus two-center" and "double-bifurcated" structural types [2]. The halogen bond involving packing patterns and their relevance to solid-state polymerization of 2,5 -dibromothiophenes were theoretically studied in [3]. Unusual $\pi-\pi$ interactions directed 
by $\left[\left\{\left(\mathrm{C}_{6} \mathrm{H}_{6}\right) \mathrm{Ru}\right\}_{2} \mathrm{~W}_{8} \mathrm{O}_{30}(\mathrm{OH})_{2}\right]^{6-}$ hybrid anions and other hybrid polyoxometalates and Ru clusters were theoretically investigated in [4,5]. Using quantum chemical calculations, we observed and studied intramolecular aurophilic interactions in dinuclear gold(I) complexes with twisted bridging 2,2'-bipyridine ligands [6]. Unexpected polymorphism in bromoantimonate(III) complexes via the system of noncovalent $\mathrm{Sb} \cdots \mathrm{Br}$ contacts and its effect on optical properties were theoretically investigated in [7]. Our group reported the crystal structure of oxochloroselenate(IV) with incorporated $\left\{\mathrm{Cl}_{2}\right\}$ units via strong $\mathrm{Cl} \cdots \mathrm{Cl}$ halogen bonding, which were studied by DFT calculations and QTAIM analysis [8]; the formation of other dichlorine-containing supramolecular complexes with chlorometalates (IV) was also discussed in [9]. Challenging the electrostatic $\sigma$-hole picture of halogen bonding using minimal models and the interacting quantum atoms approach was discussed in detail in [10]. Our group carried out the combined experimental, theoretical, and database study of $\pi-\pi$ non-covalent interaction involving 1,2,4- and 1,3,4-oxadiazole systems [11]. Trinuclear molybdenum clusters with sulfide bridges as potential anionic receptors via chalcogen bonding were discussed and theoretically studied in [12]. We theoretically study features of halogen bonding in solid state structures of $\mathrm{Zn}(\mathrm{II})$ heteroleptic halide complexes with 2-halopyridines [13]. The modulation of luminescence properties for [cyclometalated]$\mathrm{Pt}^{\mathrm{II}}$ (isocyanide) complexes upon co-crystallization with halosubstituted perfluorinated arenes and the formation of cooperative $\mathrm{C}-\mathrm{X} \cdots \mathrm{Cl}-\mathrm{Pt}$ halogen bonds and $\pi$-hole $\cdots \mathrm{d}_{\mathrm{z}}{ }^{2}\left[\mathrm{Pt}^{\mathrm{II}}\right]$ contacts were discussed in [14]. Diverse structural types and features of non-covalent interaction patterns in bromoantimonates with bis(pyridinium)-type dications obtained via oxidation by dibromine were considered in [15]. The structures, luminescence, and features of non-covalent interactions in the solid state of heteroleptic Zn(II) 3,5-diiodosalicylates and mono- and binuclear $\mathrm{Cu}$ (II) 3,5-diiodosalicylates were discussed in [16,17], respectively. The impact of the molecular structure on aggregation and solid-state luminescence of 2,3-diarylfumaronitriles were considered in [18]. The 2,3,4,5-tetraiodopyrrole as a building block for the formation of supramolecular hybrids with organic iodide salts in solid state via halogen bonding was proposed in [19]. The synthesis, structural characterization, and self-assembly of azoimidazole gold(III) complexes in the solid state were presented in [20]. The structural features and theoretical studies of I $\cdots$ I non-covalent interactions in one-dimensional supramolecular hybrid iodobismuthate $(1-\mathrm{EtPy})_{3}\left\{\left[\mathrm{Bi}_{2} \mathrm{I}_{9}\right]\left(\mathrm{I}_{2}\right)_{0.75}\right\}$ were discussed in [21]. Finally, theoretical prediction and future experimental verification of catalytic activity of azolium- and iodonium-based halogen bond donors were reported in [22,23], respectively.

I hope that other authors will follow my initiative and that readers of this Special Issue of Crystals will have the opportunity to become acquainted with the achievements of researchers in this modern topic.

Funding: This editorial article was written without attracting additional external funding from any scientific foundations. The APC for this editorial article was waived by the journal Crystals.

Institutional Review Board Statement: Not applicable.

Informed Consent Statement: Not applicable.

Data Availability Statement: Not applicable.

Conflicts of Interest: The author declares no conflict of interest.

\section{References}

1. Novikov, A.S. IsoStar program suite for studies of noncovalent interactions in crystals of chemical compounds. Crystals 2021, 11, 162. [CrossRef]

2. Aliyarova, I.S.; Ivanov, D.M.; Soldatova, N.S.; Novikov, A.S.; Postnikov, P.S.; Yusubov, M.S.; Kukushkin, V.Y. Bifurcated halogen bonding involving diaryliodonium cations as iodine(III)-based double- $\sigma$-hole donors. Cryst. Growth Des. 2021, 21, 1136-1147. [CrossRef]

3. Baykov, S.V.; Presnukhina, S.I.; Novikov, A.S.; Shetnev, A.A.; Boyarskiy, V.P.; Kukushkin, V.Y. 2,5-Dibromothiophenes: Halogen bond involving packing patterns and their relevance to solid-state polymerization. Cryst. Growth Des. 2021, 21, 2526-2540. [CrossRef] 
4. Mukhacheva, A.A.; Komarov, V.Y.; Kokovkin, V.V.; Novikov, A.S.; Abramov, P.A.; Sokolov, M.N. Unusual $\pi-\pi$ interactions directed by $\left[\left\{\left(\mathrm{C}_{6} \mathrm{H}_{6}\right) \mathrm{Ru}_{2} \mathrm{~W}_{8} \mathrm{O}_{30}(\mathrm{OH})_{2}\right]^{6-}\right.$ hybrid anion. CrystEngComm 2021, 23, 4125-4135. [CrossRef]

5. Abramov, P.A.; Novikov, A.S.; Sokolov, M.N. Interactions of aromatic rings in the crystal structures of hybrid polyoxometalates and Ru clusters. CrystEngComm 2021, 23, 6409-6417. [CrossRef]

6. Shmelev, N.Y.; Okubazghi, T.H.; Abramov, P.A.; Komarov, V.Y.; Rakhmanova, M.I.; Novikov, A.S.; Gushchin, A.L. Intramolecular aurophilic interactions in dinuclear gold(I) complexes with twisted bridging 2,2'-bipyridine ligands. Dalton Trans. 2021, 50, 12448-12456. [CrossRef] [PubMed]

7. Usoltsev, A.N.; Sukhikh, T.S.; Novikov, A.S.; Shayapov, V.R.; Pishchur, D.P.; Korolkov, I.V.; Sakhapov, I.F.; Fedin, V.P.; Sokolov, M.N.; Adonin, S.A. Unexpected polymorphism in bromoantimonate(III) complexes and its effect on optical properties. Inorg. Chem. 2021, 60, 2797-2804. [CrossRef]

8. Usoltsev, A.N.; Korobeynikov, N.A.; Kolesov, B.A.; Novikov, A.S.; Abramov, P.A.; Sokolov, M.N.; Adonin, S.A. Oxochloroselenate(IV) with incorporated $\left\{\mathrm{Cl}_{2}\right\}$ : The case of strong $\mathrm{Cl} \cdots \mathrm{Cl}$ halogen bonding. Chem. Eur. J. 2021, 27, 9292-9294. [CrossRef]

9. Usoltsev, A.N.; Korobeynikov, N.A.; Kolesov, B.A.; Novikov, A.S.; Samsonenko, D.G.; Fedin, V.P.; Sokolov, M.N.; Adonin, S.A. Rule, not exclusion: Formation of dichlorine-containing supramolecular complexes with chlorometalates(IV). Inorg. Chem. 2021, 60, 4171-4177. [CrossRef]

10. Jiménez-Grávalos, F.; Gallegos, M.; Pendás, Á.M.; Novikov, A.S. Challenging the electrostatic $\sigma$-hole picture of halogen bonding using minimal models and the interacting quantum atoms approach. J. Comput. Chem. 2021, 42, 676-687. [CrossRef]

11. Baykov, S.V.; Mikherdov, A.S.; Novikov, A.S.; Geyl, K.K.; Tarasenko, M.V.; Gureev, M.A.; Boyarskiy, V.P. $\pi-\pi$ noncovalent interaction involving 1,2,4- and 1,3,4-oxadiazole systems: The combined experimental, theoretical, and database study. Molecules 2021, 26, 5672. [CrossRef] [PubMed]

12. Novikov, A.S.; Gushchin, A.L. Trinuclear molybdenum clusters with sulfide bridges as potential anionic receptors via chalcogen bonding. CrystEngComm 2021, 23, 4607-4614. [CrossRef]

13. Vershinin, M.A.; Rakhmanova, M.I.; Novikov, A.S.; Sokolov, M.N.; Adonin, S.A. Zn(II) heteroleptic halide complexes with 2-halopyridines: Features of halogen bonding in solid state. Molecules 2021, 26, 3393. [CrossRef] [PubMed]

14. Katkova, S.A.; Luzyanin, K.V.; Novikov, A.S.; Kinzhalov, M.A. Modulation of luminescence properties for [cyclometalated]$\mathrm{Pt}^{\mathrm{II}}$ (isocyanide) complexes upon co-crystallisation with halosubstituted perfluorinated arenes. New J. Chem. 2021, 45, $2948-2952$. [CrossRef]

15. Bondarenko, M.A.; Abramov, P.A.; Plyusnin, P.E.; Novikov, A.S.; Sokolov, M.N.; Adonin, S.A. Bromoantimonates with bis(pyridinium)-type dications obtained via oxidation by dibromine: Diverse structural types and features of interactions pattern. Polyhedron 2021, 202, 115217. [CrossRef]

16. Bondarenko, M.A.; Rakhmanova, M.I.; Plyusnin, P.E.; Abramov, P.A.; Novikov, A.S.; Rajakumar, K.; Sokolov, M.N.; Adonin, S.A. Heteroleptic Zn(II) 3,5-diiodosalicylates: Structures, luminescence and features of non-covalent interactions in solid state. Polyhedron 2021, 194, 114895. [CrossRef]

17. Bondarenko, M.A.; Novikov, A.S.; Sukhikh, T.S.; Korolkov, I.V.; Sokolov, M.N.; Adonin, S.A. Mono- and binuclear Cu(II) 3,5diiodosalicylates: Structures and features of non-covalent interactions in crystalline state. J. Mol. Struct. 2021, 1244, 130942. [CrossRef]

18. Afanasenko, A.M.; Krutin, D.V.; Taishev, A.E.; Novikov, A.S.; Chulkova, T.G.; Kolesnikov, I.E.; Kornyakov, I.V.; Panikorovskii, T.L.; Vereshchagin, A.N.; Elinson, M.N. The impact of the molecular structure on aggregation and solid state luminescence of 2,3-diarylfumaronitriles. J. Mol. Struct. 2021, 1248, 131503. [CrossRef]

19. Bondarenko, M.A.; Novikov, A.S.; Abramov, P.A.; Sakhapov, I.F.; Sokolov, M.N.; Adonin, S.A. 2,3,4,5-Tetraiodopyrrole as a building block for halogen bonding: Formation of supramolecular hybrids with organic iodide salts in solid state. J. Mol. Struct. 2021, 1230, 129931. [CrossRef]

20. Tskhovrebov, A.G.; Novikov, A.S.; Tupertsev, B.S.; Nazarov, A.A.; Antonets, A.A.; Astafiev, A.A.; Kritchenkov, A.S.; Kubasov, A.S.; Nenajdenko, V.G.; Khrustalev, V.N. Azoimidazole gold(III) complexes: Synthesis, structural characterization and self-assembly in the solid state. Inorg. Chim. Acta 2021, 522, 120373. [CrossRef]

21. Usoltsev, A.N.; Korobeynikov, N.A.; Novikov, A.S.; Shayapov, V.R.; Korolkov, I.V.; Samsonenko, D.G.; Fedin, V.P.; Sokolov, M.N.; Adonin, S.A. One-dimensional supramolecular hybrid iodobismuthate $(1-\mathrm{EtPy})_{3}\left\{\left[\mathrm{Bi}_{2} \mathrm{I}_{9}\right]\left(\mathrm{I}_{2}\right)_{0.75}\right\}$ : Structural features and theoretical studies of I ...I non-covalent interactions. J. Clust. Sci. 2021, 32, 787-791. [CrossRef]

22. Sysoeva, A.A.; Novikov, A.S.; Il'in, M.V.; Suslonov, V.V.; Bolotin, D.S. Predicting the catalytic activity of azolium-based halogen bond donors: An experimentally-verified theoretical study. Org. Biomol. Chem. 2021, 19, 7611-7620. [CrossRef] [PubMed]

23. Yunusova, S.N.; Novikov, A.S.; Soldatova, N.S.; Vovk, M.A.; Bolotin, D.S. Iodonium salts as efficient iodine(III)-based noncovalent organocatalysts for Knorr-type reactions. RSC Adv. 2021, 11, 4574-4583. [CrossRef] 